\title{
The rhizome layer of Posidonia oceanica: an important habitat for Mediterranean brachiopods
}

\author{
Paolo G. Albano ${ }^{1}$ (D) Martina Stockinger ${ }^{1}$ \\ Received: 21 March 2019 / Revised: 7 May 2019 / Accepted: 10 May 2019 / Published online: 14 June 2019 \\ (C) The Author(s) 2019
}

\begin{abstract}
Mediterranean brachiopods are elusive organisms to find alive even if the bathymetric range of some species extends to very shallow waters. We here record an abundant population of Joania cordata (Risso, 1826) and Argyrotheca cuneata (Risso, 1826) in the rhizome layer of a Posidonia oceanica (Linné) Delile, 1813 meadow in Plakias, southwestern Crete from 5 to $20 \mathrm{~m}$ depth. Altogether, we collected 963 living individuals and 4309 shells by suction sampling; it is the largest collection of living brachiopods in Posidonia meadows ever reported. Although literature records on the occurrence of shallow-water brachiopods in this habitat are few, we claim that Posidonia rhizomes are a particularly suitable infralittoral habitat for these organisms due to their sciaphilous conditions. Suction sampling is an effective technique to collect them and can enable the discovery of many more populations in the Mediterranean Sea.
\end{abstract}

Keywords Joania cordata $\cdot$ Argyrotheca cuneata $\cdot$ Seagrass $\cdot$ Suction sampling $\cdot$ Crete $\cdot$ Eastern Mediterranean Sea

\section{Introduction}

The present-day Mediterranean Sea hosts only 14 species of brachiopods (Logan et al. 2004; Robinson 2017) which prefer habitats with low illumination and are generally reported from coralligenous substrates, coralline algae frameworks typical of the Mediterranean Sea, below $40 \mathrm{~m}$. Some species are known to occur also in shallower waters but only in shaded and protected environments such as caves and beneath boulders (Logan 1979). Shallow-water species are often reported as empty shells from death assemblages whereas findings of living individuals are uncommon and usually limited to a few individuals (e.g. Taddei Ruggiero 1994; Grobe and Lüter 1999; Evangelisti et al. 2011).

We here report an abundant collection of two megathyrid brachiopods, Joania cordata (Risso, 1826) and Argyrotheca cuneata (Risso, 1826), in the rhizome layer of Posidonia oceanica (Linné) Delile, 1813 between 5 and $20 \mathrm{~m}$ depth from

Communicated by M. Yasuhara

Paolo G. Albano

pgalbano@gmail.com

1 Department of Palaeontology, University of Vienna, Althanstrasse 14, 1090 Vienna, Austria southwestern Crete. We found hundreds of living individuals and thousands of shells of both species. We claim that direct sampling of this habitat with proper methods, such as suction sampling, can lead to the discovery of similarly abundant populations elsewhere in the Mediterranean Sea.

\section{Material and methods}

We sampled a Posidonia oceanica meadow in Plakias, southwestern Crete $\left(35.1796^{\circ} \mathrm{N}, 24.3957^{\circ} \mathrm{E}\right.$, Fig. 1), from 5 to $20 \mathrm{~m}$ depth at 5-m intervals on 8-21 May and 14-27 September 2017. Organisms on the leaves were collected with a net mounted on a metal frame with a $40 \times 20$-cm opening (Buia et al. 2003). The rhizomes were sampled with air-lift suction sampling (Templado et al. 2010). The sampler consisted of a PVC tube with a length and diameter of $100 \mathrm{~cm}$ and $8 \mathrm{~cm}$, respectively. A SCUBA cylinder supplied air and was fitted at $10 \mathrm{~cm}$ above the mouth of the tube. At its other end, we attached a removable $0.5-\mathrm{mm}$ mesh nylon bag that could be closed and replaced underwater. Sampling on the rhizomes was carried out on $1-\mathrm{m}^{2}$ square areas after defoliation in order to enhance collecting efficacy (Bonfitto et al. 1998). Three replicates per season were sampled at each depth. To assess the Posidonia bed structure, the plant shoot density was 
Fig. 1 Geographic location of the study site Plakias, southwestern Crete, in the eastern Mediterranean Sea

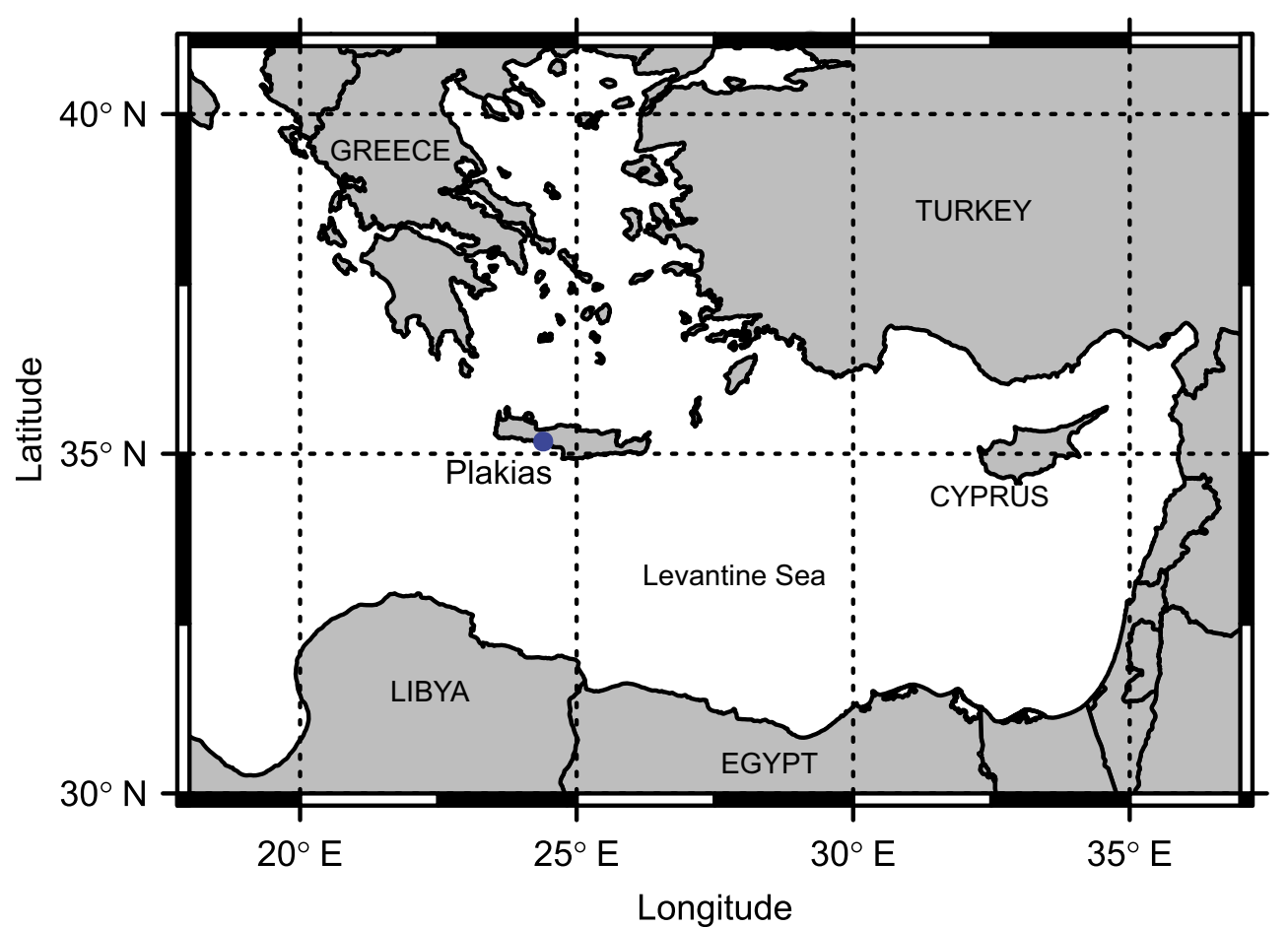

quantified by counting on a $40 \times 40$-cm square area within each $1 \mathrm{~m}^{2}$ sampled with the air-lift suction sampler.

Samples were sieved with a 1-mm mesh size and sorted under a stereomicroscope in seawater to pick living organisms more easily. The residue was dried and again sorted to pick the empty shells, valves, and overlooked living organisms.

We identified each specimen to the species level on the basis of Logan's review (Logan 1979), counted the individuals, the empty shells, and the valves (as half shell). Photographs were taken using a Zeiss SteREO Discovery.V20 stereomicroscope at multiple focus levels and stacked with Helicon Focus 6 (Helicon Soft Ltd., Roseau Valley, Dominica).

Quantitative data have been deposited in the OBIS database and the samples in the Natural History Museum in Vienna (inventory numbers NHMW 112930/LM/0201 to NHMW 112930/LM/0350 (Mollusca collection)).

\section{Results}

We found 963 living brachiopods: 685 Joania cordata and 278 Argyrotheca cuneata. The great majority was found in the samples from the rhizomes (Fig. 2), but six were also found in the leaf samples. In the rhizomes, both species were abundant at all depths, but we noted a peak in total and mean abundance at 15-m depth (Table 1). We found also 4309 shells: 3231 Joania cordata, 1074 Argyrotheca cuneata, 3 Megathiris detruncata (Gmelin, 1791), and 1 valve of Novocrania anomala (Müller, 1776). Although we noted a more abundant living and death assemblage in autumn than in spring, we did not isolate data per season because we suspect that such a pattern could be an artifact of a more intense suction during the autumn fieldwork. The size of both living specimens and empty shells rarely exceeds $4 \mathrm{~mm}$, fully conforming with the size reported for the Mediterranean Sea (Logan 1979).

Most living brachiopods were attached with their pedicle to any hard substrate available such as rhizome fragments, coralline algae, sessile foraminifera, bryozoan colonies, and even inside empty gastropod shells (Fig. 3). The Posidonia shoot density declined monotonically with depth (Fig. 4). The meadow hosted a rich community which was dominated by grazers on the leaves, and was more functionally and taxonomically diverse in the rhizomes.

\section{Discussion}

Joania cordata and Argyrotheca cuneata are two common brachiopods in the Mediterranean Sea and were reported in shallow water also from Greece (Gerovasileiou and Bailly 2016), including Crete (Logan 1979; Brunton 1988; Logan et al. 2002). Their presence in Posidonia oceanica meadows was first reported from death assemblages in southern Italy (Taddei Ruggiero 1985). Joania cordata was then reported alive in Posidonia oceanica rhizomes for the first time on an off-shore reef in the Tyrrhenian Sea: 7 living individuals, along with 97 shells, were collected by suction sampling (Evangelisti et al. 2011). This reef hosted small seagrass 
Fig. 2 The rhizome layer of the Posidonia oceanica meadow in Plakias, southwestern Crete. The rhizomes host one of the most diverse invertebrate assemblages in the Mediterranean Sea

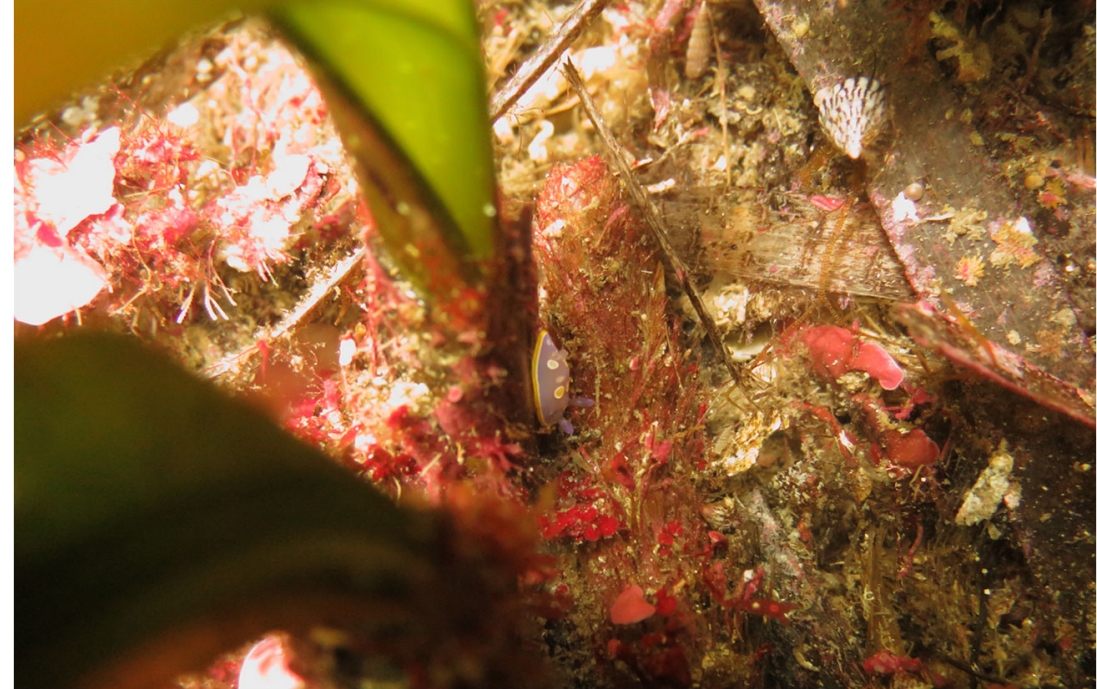

patches on a hard substrate covered by extensive coralligenous concretions with similar but distinct molluscan assemblages characterized by the presence of several species typical of deeper sciaphilous environments (Albano and Sabelli 2011, 2012). Although we found a few specimens also in the leaf samples, in the Crete meadow, these brachiopods definitely prefer the rhizomes and their low hydrodynamism and dim light. Moreover, this layer has plenty of small and large objects for the brachiopods to attach such as the rhizome themselves and other plant debris, shells, foraminiferal tests, and bryozoan colonies (Fig. 3). Nonetheless, because the shoot density declined monotonically with depth, the abundance peak at 15-m depth, which is particularly remarkable for Joania cordata, cannot be easily explained by a calmer or darker environment. Megathyrid brachiopods were found in similar sciaphilic and cryptic habitats also in other regions such as the Caribbean (Asgaard and Stentoft 1984), the Red Sea (Zuschin and Mayrhofer 2009), and the Bay of Fundy, eastern Canada (Noble et al. 1976). The habit of most brachiopods to settle in such habitats may have evolved as a response to the increasing occurrence of grazing invertebrates (e.g. gastropods) during the Mesozoic (Witman and Cooper 1983; Tomašových 2008a, b; Radley 2010).

Megathiris detruncata and Novocrania anomala were not found alive. M. detruncata is rare in so shallow waters, its optimum range being 20-160 m (Logan 1979). Still, the presence of shells suggests that also this species can be encountered alive, albeit rarely, in Posidonia meadows. Novocrania anomala does occur in very shallow waters but lives cemented to boulder and shell substrates (Logan 1979). Suitable hard substrates may be rare among the rhizomes and in any case difficult to intercept with our sampling gear.

The absence of previous records of abundant living brachiopods in the rhizome layer may be due to the difficulties in sampling this habitat. Brachiopods are too small to be seen and picked individually. Grabs and other indirect methods do not easily penetrate the matte, and, in any case, they would be extremely damaging for the seagrass meadow. For similar reasons, the collection of pieces of rhizomes to be inspected in the laboratory, similar to the direct or indirect collecting of rocks and coralligenous concretions, is not advisable; moreover, cutting into the dense matte would be extremely

Table 1 Total and mean abundance per square meter of living brachiopods and empty shells in the rhizome layer of the Posidonia oceanica meadow in Plakias, southwestern Crete

\begin{tabular}{|c|c|c|c|c|c|c|c|c|}
\hline \multirow[b]{3}{*}{ Depth (m) } & \multicolumn{4}{|c|}{ Joania cordata } & \multicolumn{4}{|c|}{ Argyrotheca cuneata } \\
\hline & \multicolumn{2}{|l|}{ Living } & \multicolumn{2}{|l|}{ Shells } & \multicolumn{2}{|l|}{ Living } & \multicolumn{2}{|l|}{ Shells } \\
\hline & $\begin{array}{l}\text { Total } \\
\text { abundance }\end{array}$ & $\begin{array}{l}\text { Mean } \\
\text { abundance }\end{array}$ & $\begin{array}{l}\text { Total } \\
\text { abundance }\end{array}$ & $\begin{array}{l}\text { Mean } \\
\text { abundance }\end{array}$ & $\begin{array}{l}\text { Total } \\
\text { abundance }\end{array}$ & $\begin{array}{l}\text { Mean } \\
\text { abundance }\end{array}$ & $\begin{array}{l}\text { Total } \\
\text { abundance }\end{array}$ & $\begin{array}{l}\text { Mean } \\
\text { abundance }\end{array}$ \\
\hline 5 & 168 & $28 \pm 33$ & 324 & $54 \pm 62$ & 64 & $11 \pm 11$ & 165 & $28 \pm 32$ \\
\hline 10 & 177 & $30 \pm 16$ & 762 & $127 \pm 88$ & 57 & $10 \pm 8$ & 200 & $33 \pm 19$ \\
\hline 15 & 243 & $41 \pm 23$ & 1210 & $202 \pm 156$ & 83 & $14 \pm 12$ & 344 & $57 \pm 45$ \\
\hline 20 & 92 & $15 \pm 5$ & 936 & $156 \pm 66$ & 73 & $12 \pm 3$ & 366 & $61 \pm 21$ \\
\hline
\end{tabular}



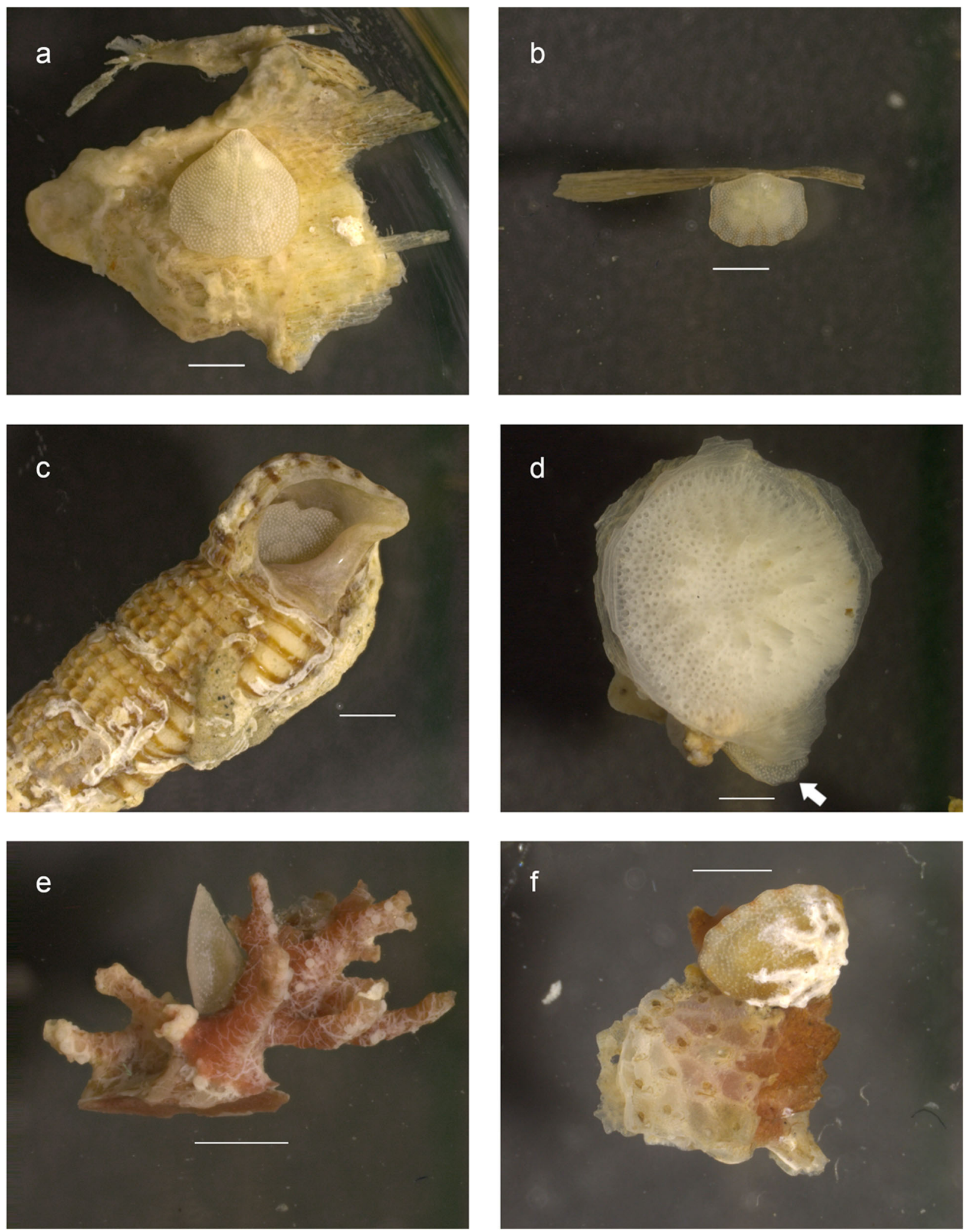

Fig. 3 Living brachiopods from the rhizome layer of the Posidonia oceanica meadow in Plakias, southwestern Crete Greece. a Joania cordata on plant debris, $-20 \mathrm{~m}$; b Argyrotheca cuneata on plant debris, $-20 \mathrm{~m}$; c Joania cordata inside the aperture of an empty shell of the gastropod Bittium latreillii (Payraudeau, 1826), - $10 \mathrm{~m}$; d Joania

cordata beneath the bryozoan Patinella radiata (Audouin, 1826), $-10 \mathrm{~m}$; e Joania cordata attached to the foraminiferan Miniacina miniacea (Pallas, 1766), - $20 \mathrm{~m}$; f Argyrotheca cuneata attached to the foraminiferan Miniacina miniacea (Pallas, 1766) covered by a bryozoan colony of Hippaliosina depressa (Busk, 1854). Scale bar $1 \mathrm{~mm}$ 


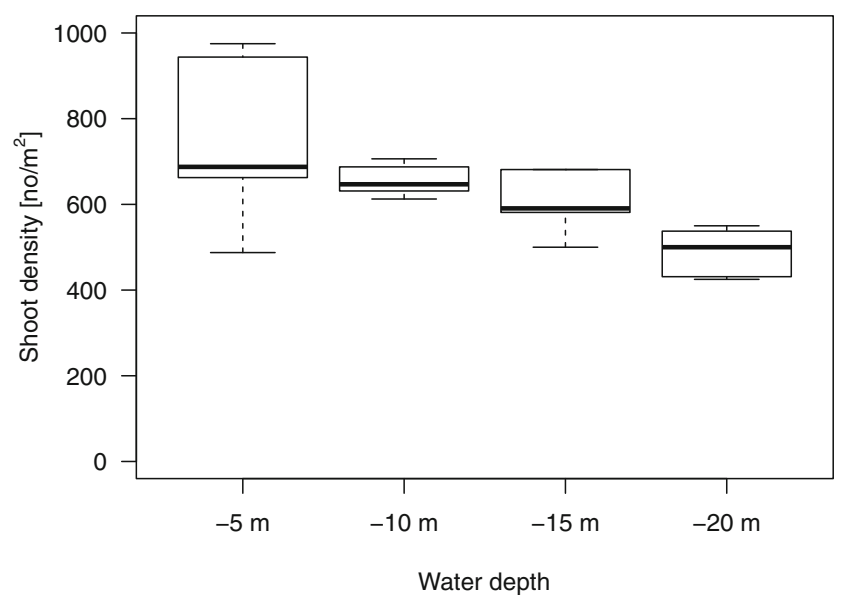

Fig. 4 Shoot density per square meter of the Posidonia oceanica meadow in Plakias, southwestern Crete

laborious and strenuous. Suction sampling offers a practical alternative that enables collecting small organisms effectively with minimal harm to the substrate. It can be operated with a diver tank or a motorized pump (Templado et al. 2010) and enables the collection of large amounts of organisms and species perfectly suiting biodiversity inventory needs (Bouchet et al. 2002; Linnane et al. 2003; Albano et al. 2011; Ringvold et al. 2015; Evans et al. 2018). We think that the lack of appropriate sampling approaches has prevented the discovery of shallow-water brachiopod populations in other Posidonia meadows so far. This habitat is easily accessible and can offer large sample sizes of living individuals and shells for biological and ecological studies (e.g. Grobe and Lüter 1999; Lüter 2001; Evangelisti et al. 2012, 2014).

Acknowledgements PGA research in the Eastern Mediterranean is in the framework of the project "Historical ecology of Lessepsian migration" (PI: PGA) funded by the Austrian Science Fund (FWF) P28983-B29. MS's fieldwork was supported by the Kurzfristige wissenschaftliche Auslandsstipendien of the University of Vienna, the non-profit organization Mare Mundi, and the diving school Dive2gether. We thank Martin Zuschin for his support during the project, Denny Morchner and Nadja Loferer for their help in the field and in the lab, and Emanuela Di Martino for the identification of the bryozoans. We also thank Adam Tomašových and an anonymous reviewer for useful comments on a first version of the manuscript.

Funding Information Open access funding provided by University of Vienna.

\section{Compliance with ethical standards}

Conflict interest The authors declare that they have no conflict of interest.

Ethical approval No animal testing was performed during this study.

Sampling and field studies No permits were required to conduct our fieldwork. The study is compliant with CBD and Nagoya protocols.
Data availability Quantitative data have been deposited in the OBIS database and the samples in the Natural History Museum in Vienna (inventory numbers NHMW 112930/LM/0201 to NHMW 112930/LM/ 0350 Mollusca collection).

Open Access This article is distributed under the terms of the Creative Commons Attribution 4.0 International License (http:// creativecommons.org/licenses/by/4.0/), which permits unrestricted use, distribution, and reproduction in any medium, provided you give appropriate credit to the original author(s) and the source, provide a link to the Creative Commons license, and indicate if changes were made.

\section{References}

Albano PG, Sabelli B (2011) Comparison between death and living molluscs assemblages in a Mediterranean infralittoral off-shore reef. Palaeogeogr Palaeoclimatol Palaeoecol 310:206-215. https://doi. org/10.1016/j.palaeo.2011.07.012

Albano PG, Sabelli B (2012) The molluscan assemblages inhabiting the leaves and rhizomes of a deep water Posidonia oceanica settlement in the Central Tyrrhenian Sea. Sci Mar 76:721-732. https://doi.org/ 10.3989/scimar.03396.02C

Albano PG, Sabelli B, Bouchet P (2011) The challenge of small and rare species in marine biodiversity surveys: microgastropod diversity in a complex tropical coastal environment. Biodivers Conserv 20:3223 3237. https://doi.org/10.1007/s10531-011-0117-x

Asgaard U, Stentoft N (1984) Recent micromorph brachiopods from Barbados: Palaeoecological and evolutionary implications. Geobios 17:29-37. https://doi.org/10.1016/S0016-6995(84)801539

Bonfitto A, Fellagara I, Gillone G (1998) Sampling techniques and structure of the malacofauna associated to the rhizome zone in Posidonia oceanica (L.) Delile. Bollettino Malacologico 33:83-88

Bouchet P, Lozouet P, Maestrati P, Heros V (2002) Assessing the magnitude of species richness in tropical marine environments: exceptionally high numbers of molluscs at a New Caledonia site. Biol J Linn Soc 75:421-436. https://doi.org/10.1046/j.1095-8312.2002.00052. $\mathrm{x}$

Brunton CHC (1988) Some brachiopods from the eastern Mediterranean Sea. Isr J Zool 35:151-169. https://doi.org/10.1080/00212210.1988. 10688609

Buia MC, Gambi MC, Dappiano M (2003) I sistemi a fanerogame marine. In: Gambi MC and Dappiano M (eds) Manuale di metodologie di campionamento e studio del benthos marino mediterraneo. Società Italiana di Biologia Marina 10 (suppl): 145-198

Delile AR (1813) Description de l'Égypte, ou Recueil des observations et des recherches qui ont été faites en Égypte pendant l'expédition de l'armée française, publié par les orderes de Sa Majesté 1'Empereur Napoléon le Grand. Histoire naturelle. Imprimerie Impériale, Paris

Evangelisti F, Albano PG, Sabelli B (2011) Recent Brachiopoda of the marine protected area "Secche di Tor Paterno", Central Tyrrhenian Sea. Cahiers de Biologie Marine 52:193-202

Evangelisti F, Albano PG, Sabelli B (2012) Predation on two brachiopods, Joania cordata and Argyrotheca cuneata, from an offshore reef in the Tyrrhenian Sea. Mar Biol 159:2349-2358. https://doi. org/10.1007/s00227-012-2019-1

Evangelisti F, Albano PG, Sabelli B (2014) Size-frequency distributions of Joania cordata and Argyrotheca cuneata (Brachiopoda: Megathyrididae) from the Central Tyrrhenian Sea. Mar Ecol 35: 377-386. https://doi.org/10.1111/maec.12096

Evans J, Attrill MJ, Borg JA et al (2018) Hidden in plain sight: species richness and habitat characterisation of sublittoral 
pebble beds. Mar Biol 165:35. https://doi.org/10.1007/s00227018-3292-4

Gerovasileiou V, Bailly N (2016) Brachiopoda of Greece: an annotated checklist. Biodiversity Data Journal 4:e8169. https://doi.org/10. 3897/BDJ.4.e8169

Gmelin JF (1791) Vermes. In: Gmelin JF (ed) Caroli a Linnaei Systema Naturae per Regna Tria Naturae, 13th edn. G.E. Beer, Lipsiae [Leipzig], pp 3021-3910

Grobe P, Lüter C (1999) Reproductive cycles and larval morphology of three recent species of Argyrotheca (Terebratellacea: Brachiopoda) from Mediterranean submarine caves. Mar Biol 134:595-600. https://doi.org/10.1007/s002270050574

Linnane A, Ball B, Munday B et al (2003) Faunal description of an Irish cobble site using airlift suction sampling. Biol Environ: Proc Royal Irish Acad 103B:41-48

Logan A (1979) The recent Brachiopoda of the Mediterranean Sea. Bull l'Institut Océanogr Monaco 72:1-112

Logan A, Bianchi CN, Morri C et al (2002) New records of recent brachiopods from the eastern Mediterranean. Ann Mus Civ Stor Nat Giacomo Doria 94:407-418

Logan A, Bianchi CN, Morri C, Zibrowius H (2004) The present-day Mediterranean brachiopod fauna: diversity, life habits, biogeography and paleobiogeography. Sci Mar 68:163-170. https://doi.org/ 10.3989/scimar.2004.68s1163

Lüter C (2001) Larval brooding and development of the micromorph rhynchonellid Tethyrhynchia mediterranea (Brachiopoda: recent). J Mar Biol Assoc U K 81:939-942. https://doi.org/10.1017/ S0025315401004866

Müller OF (1776) Zoologiae Danicae prodromus, seu animalium Daniae et Norvegiae indigenarum: characteres, nomina, et synonyma imprimis popularium. Hallagerii, Copenhague

Noble JPA, Logan A, Webb GR (1976) The recent Terebratulina community in the rocky subtidal zone of the Bay of Fundy. Canada Lethaia 9:1-18. https://doi.org/10.1111/j.1502-3931.1976.tb00942. $\mathrm{x}$

Radley JD (2010) Grazing bioerosion in Jurassic seas: a neglected factor in the Mesozoic marine revolution? Hist Biol 22:387-393. https:// doi.org/10.1080/08912961003673079

Ringvold H, Grytnes J-A, van der Meeren GI (2015) Diver-operated suction sampling in Norwegian cobble grounds: technique and associated fauna. Crustaceana 88:184-202. https://doi.org/10.1163/ 15685403-00003406
Risso A (1826) Histoire naturelle des principales productions de l'Europe Méridionale et particulièrement de celles des environs de Nice et des Alpes Maritimes. Tome quatrième. F.-G. Levrault, Paris

Robinson JH (2017) A review of all recent species in the genus Novocrania (Craniata, Brachiopoda). Zootaxa 4329:501-559. https://doi.org/10.11646/zootaxa.4329.6.1

Taddei Ruggiero E (1985) Megathyrididae (Brachiopoda) attuali raccolti lungo le coste della Campania e della Puglia. Boll Soc Nat Napoli 94:255-285

Taddei Ruggiero E (1994) Brachiopods from bio- and thanatocoenoses of the Isca submarine cave (Sorrento Peninsula). In: Matteucci R et al (eds) Studies on the ecology and paleoecology of benthic communities. Bollettino della Società Paleontologica Italiana Special, vol 2, pp 313-323

Templado J, Paulay G, Gittenberger A, Meyer C (2010) Sampling the marine realm. In: Eymann J, Degreef J, Häuser C, et al. (eds) Manual on field recording techniques and protocols for all taxa biodiversity inventories, ABC Taxa 8(1):273-302

Tomašových A (2008a) Substrate exploitation and resistance to biotic disturbance in the brachiopod Terebratalia transversa and the bivalve Pododesmus macrochisma. Mar Ecol Prog Ser 363:157-170. https://doi.org/10.3354/meps07472

Tomašových A (2008b) Evaluating neutrality and the escalation hypothesis in brachiopod communities from shallow, high-productivity habitats. Evol Ecol Res 10:667-698

Witman JD, Cooper RA (1983) Disturbance and contrasting patterns of population structure in the brachiopod Terebratulina septentrionalis (Couthouy) from two subtidal habitats. J Exp Mar Biol Ecol 73:57-79. https://doi.org/10.1016/00220981(83)90005-9

Zuschin M, Mayrhofer S (2009) Brachiopods from cryptic coral reef habitats in the northern Red Sea. Facies 55:335-344. https://doi. org/10.1007/s10347-009-0189-1

Publisher's note Springer Nature remains neutral with regard to jurisdictional claims in published maps and institutional affiliations. 